Accepted refereed manuscript of: Hooper T, Börger T, Langmead O, Marcone O, Rees SE, Rendon O, Beaumont N, Attrill MJ \& Austen M (2019) Applying the natural capital approach to decision making for the marine environment. Ecosystem Services, 38, Art. No.: 100947. DOI: https://doi.org/10.1016/i.ecoser.2019.100947

(C) 2019, Elsevier. Licensed under the Creative Commons Attribution-NonCommercial-NoDerivatives 4.0 International http://creativecommons.org/licenses/by-nc-nd/4.0/

\title{
Applying the natural capital approach to decision making for the marine environment
}

Tara Hooper ${ }^{\star 1}$, Tobias Börger ${ }^{2}$, Olivia Langmead ${ }^{3,4}$, Oceane Marcone ${ }^{1}$, Siân E Rees ${ }^{3}$, Olivia Rendon¹, Nicola Beaumont ${ }^{1}$, Martin J Attrill ${ }^{3}$ and Melanie Austen ${ }^{1}$.

* Corresponding author: tarh@pml.ac.uk

1. Plymouth Marine Laboratory, Prospect Place, The Hoe, Plymouth, Devon, PL1 3DH, UK

2. University of St Andrews, College Gate, North Street, St Andrews, Fife, KY16 9AJ, UK

3. Marine Institute, University of Plymouth, Drake Circus, Plymouth, Devon PL4 8AA, UK

4. Marine Biological Association of the UK, The Laboratory, Citadel Hill, Plymouth, Devon, PL1 2PB

\begin{abstract}
The aspirations for natural capital and ecosystem service approaches to support environmental decision-making have not been fully realised in terms of their actual application in policy and management contexts. Application of the natural capital approach requires a range of methods, which as yet have not been fully tested in the context of decision making for the marine environment. It is unlikely that existing methodologies, which were developed for terrestrial systems and are based on land cover assessment approaches, will ever be feasible in the marine context at the national scale. Land cover approaches are also fundamentally insufficient for the marine environment because they do not take account of the water column, the significant interconnections between spatially disparate components, or the highly dynamic nature of the marine ecosystem, for example the high spatial mobility of many species. Data gaps have been a significant impediment to progress, so alternative methods that use proxies for quality information as well as the opportunities for remote sensing should be explored further. Greater effort to develop methodologies specifically for the marine environment is required, which should be interdisciplinary and cross-sectoral, coherent across policy areas, and applicable across a range of contexts.
\end{abstract}

\section{Introduction}

The potential of ecosystem services and natural capital approaches to support decision making for improved environmental outcomes is much vaunted. However, it is well documented that there remains a disconnect between academic research and actual integration into policy frameworks and subsequent decision making (Laurans et al., 2013; Primmer et al., 2018; Barton et al., 2018).

The UK has a receptive policy landscape for the adoption of natural capital approaches. It was the first country globally to attempt a national-scale assessment of the benefits provided by nature to society 
and the economy, an endeavour part-funded by the UK Government and devolved administrations (UK National Ecosystem Assessment, 2011; 2014). An Environment White Paper (HM Government, 2011) further enshrined natural capital thinking within UK environmental policy, with commitments to include natural capital within the UK Environmental Accounts and to establish a Natural Capital Committee to advise government. Most recently, the 25 Year Environment Plan (HM Government, 2018) reaffirmed the government's position that the environment underpins well-being and prosperity and provides quantifiable economic benefits, and explicitly stated that "over the coming years the UK intends to use a 'natural capital' approach as a tool to help us make key choices and long-term decisions". The Plan further outlined the intention to reframe financial incentives for land and fisheries management in the context of improving ecosystem service delivery, aspirations which have the potential to be reinforced by upcoming agricultural and fisheries legislation (Agriculture Bill, 2018; Fisheries Bill, 2018).

Such unequivocal language sends a clear signal of high-level policy intent, but this must be underpinned by guidance, methods and tools that allow the approach to be implemented in practice. Application of the natural capital approach to the marine environment presents particular challenges, not least in that it suffers knowledge and governance deficits, perhaps more than any other ecosystem (Beaudoin \& Pendleton, 2012). Also, coasts and seas cross borders and jurisdictions not coincident with the scale of the ecological processes, which includes interaction with terrestrial systems (Turner et al., 2014), bringing challenges for management and governance. Furthermore, most effort in developing the natural capital approach has focused on terrestrial systems (Liquete et al., 2013). The complexity of the marine environment (and the challenges of collecting data on it) often requires modification of methods and strategies.

In this paper, we examine the extent to which the natural capital approach is sufficiently operationalised to support decision making for the marine environment, focusing mainly on the context of UK policy. The UK has been chosen for its conducive policy environment, but we also bring in international examples, particularly from the European Union. We describe the frameworks (Section 2) and mechanisms (Section 3) needed to apply the approach, bringing together examples of where these have been used in marine and coastal contexts. We then discuss whether they are fit for purpose for the marine environment (Section 4), including highlighting key challenges and suggesting where alternative approaches are required. We make extensive use of grey literature, as this is often commissioned by, or otherwise prepared in collaboration with, government departments, statutory nature conservation bodies, local authorities, non-governmental organisations and businesses, and thus provides direct links to natural capital practice, which academic literature often lacks.

\section{Natural capital frameworks}

\subsection{Conceptual framework}

In the UK policy context, the Natural Capital Committee (2014) sought to formalise a conceptual approach to natural capital assessment (Figure 1), which recognises that: (i) there is a set of natural 
capital stocks (the assets); (ii) each natural capital stock may provide one or more services; these are outputs or features of each stock; (iii) services, often combined with 'other capital inputs', can be used to produce goods [which] are what people receive and use from natural capital stocks; and (iv) 'Goods' are consumed / used and provide benefits (to people) which can be valued (often in monetary terms). Major land-use categories are proposed as accounting units for natural capital.

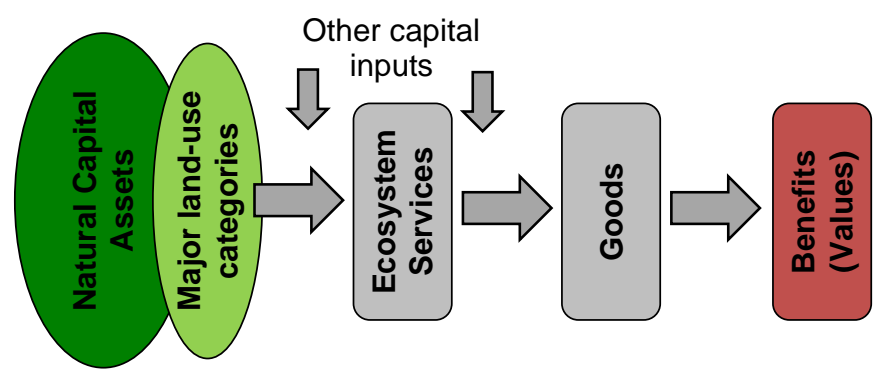

Figure 1. The natural capital conceptual framework (Natural Capital Committee, 2014)

The concept of ecosystem services, and attempts to operationalise it, was the focus of early attention through standalone approaches, and remains a key element of the broader natural capital structure. The importance of conceptual frameworks such as the Millennium Ecosystem Assessment (MA; 2003), The Economics of Ecosystems and Biodiversity (TEEB; 2010) and the UK National Ecosystem Assessment (UK NEA, 2011) in developing the ecosystem services component of the natural capital approach (as well as the wider academic research that underpinned and evaluated them) cannot be overstated. They have led to a broad convergence around (i) high-level classification of services within the provisioning, regulating and cultural categories, and (ii) propounding the fundamental principles that only ecosystem endpoints should be valued and that value comprises much more than the monetary component.

This latter point is reiterated within guidance for practitioners, which recognises that it is not always possible to monetise natural capital, and that natural capital accounts using non-monetary metrics also have considerable power (HM Government, 2018; HM Treasury, 2018; Vardon et al., 2017). The depiction in conceptual frameworks of linear chains or cascades from ecological processes through services to economic value (as in, for example, Figure 1) perhaps compounded the notion that the overall objective of the natural capital approach was to derive monetary values. However, it is increasingly being emphasised that all components of the approach should be considered holistically: the measurement of the status of natural capital stocks (not just the marginal valuation of current flows of services and benefits) is vital to ensure that these are maintained and can continue to provide services into the future (HM Treasury, 2018).

\subsection{Classification Frameworks}

\subsubsection{Ecosystem Services}


There have been a number of attempts to undertake marine ecosystem service assessments (including, with reference to the UK, Atkins et al., 2011; Beaumont et al., 2007, 2008; Böhnke-Henrichs et al., 2013; Dickie et al., 2014; Everard et al., 2010; Hattam et al., 2015; Hooper et al., 2014; Hussain et al., 2010; Jones et al., 2011; Liquete et al., 2013; Norton et al., 2018; Saunders et al, 2010; Turner et al., 2014, 2015). In these, researchers have rarely used overarching frameworks such as the MA, TEEB or UK NEA without first modifying them to suit the specific circumstances. This suggests that the overarching frameworks provide a strong conceptual basis for ecosystem service assessment, but do not provide a standard operational classification that can be universally applied in practice. It has been argued that the development of a standard classification framework is essential, to prevent confusion, maximise accessibility and increase the comparability and transferability of assessments between different locations, issues and scales (Beaumont et al., 2007; Haines-Young \& Potschin, 2010; Saunders et al., 2010; Wallace, 2007). However, the difficulties of successfully developing a universally accepted, operationally effective classification system are also well documented, with some authors questioning whether this could ever be achieved (Costanza, 2008; de Groot et al., 2002; Fisher et al., 2009).

The Common International Classification of Ecosystem Services (CICES; Haines-Young \& Potschin, $2013 ; 2018$ ) is one of the most commonly used classification systems globally (and particularly in Europe) and has been used by government agencies as well as academics (La Notte et al., 2017). It has also been endorsed as a classification framework for the development of natural capital accounts in the Dutch North Sea (Graveland et al., 2017). The most recent comprehensive revision (for CICES v5.1, released in 2018) took more explicit account of its relevance for marine and coastal ecosystems, based on a review of the previous version (v4.3) and its use in developing an operational assessment framework to support EU policy needs (Haines-Young \& Potschin, 2018). Full details of this process and its conclusions are not in the public domain, although Culhane et al. (2018) provide a list of 33 marine-relevant ecosystem services as derived from CICES v4.3.

\subsubsection{Habitat classifications}

The foundation for natural capital assessment is the definition of the underlying ecological components for which the assessment is taking place. The term Service Providing Unit (SPU) was coined, initially, to describe the group of individuals that provides one or more ecosystem services, while recognising that the definition of any SPU would vary according to context, particularly in terms of spatial and temporal scales (Luck et al. 2003).

In their conceptual framework for the UK (Figure 1), the Natural Capital Committee (2014) proposed that the broad habitat types defined within the UK NEA (2011) are used as the basic SPUs for assessment, as these form the basis of existing monitoring schemes, are mutually exclusive, and cover the entire country. This includes the categories of coastal margins and marine habitats (Table 1). An alternative typology of coastal and marine habitats has been proposed by the European Union's Mapping and Assessment of Ecosystem Services (MAES) initiative, which links to the European Nature Information System (EUNIS) and Marine Strategy Framework Directive (MSFD) classifications (Maes 
et al., 2013) and also explicitly includes pelagic systems, which are largely absent from the UK NEA classification.

Table 1. Mapping coastal and marine habitats typologies as proposed for the UK by National Ecosystem Assessment (UK NEA, 2011) and in the European Union context by the Mapping and Assessment of Ecosystem Services (MAES) initiative (Maes et al., 2013)

\begin{tabular}{|c|c|c|c|c|c|c|}
\hline \multicolumn{2}{|c|}{ Zone } & Category & UKNEA & $\begin{array}{l}\text { Habitat } \\
\text { class }\end{array}$ & Habitat & Habitat class(es) \\
\hline \multicolumn{2}{|c|}{ 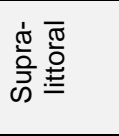 } & $\begin{array}{l}\text { Land } \\
\text { cover }\end{array}$ & $\begin{array}{l}\text { Sand dunes } \\
\text { Machair } \\
\text { Shingle } \\
\text { Sea cliffs }\end{array}$ & & & \\
\hline \multirow{2}{*}{\multicolumn{2}{|c|}{ 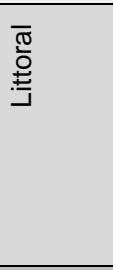 }} & Pelagic & Coastal lagoons & $\begin{array}{l}\text { Coastal } \\
\text { margin }\end{array}$ & $\begin{array}{l}\text { Low/reduced salinity water (of lagoons) } \\
\text { Variable salinity water (coastal wetlands, } \\
\text { estuaries, other transitional waters) } \\
\text { Marine salinity water (of other inlets) } \\
\text { Coastal waters }\end{array}$ & \multirow{4}{*}{$\begin{array}{l}\text { Marine inlets and } \\
\text { transitional waters; } \\
\text { Coastal }\end{array}$} \\
\hline & & Benthic & $\begin{array}{l}\text { Saltmarsh } \\
\text { Intertidal rock } \\
\text { Intertidal sediments }\end{array}$ & & $\begin{array}{l}\text { Littoral rock \& biogenic reef } \\
\text { Littoral sediment }\end{array}$ & \\
\hline \multirow{6}{*}{ 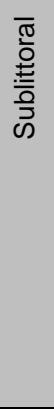 } & 3 & Pelagic & & \multirow{6}{*}{ Marine } & Coastal waters & \\
\hline & $\begin{array}{l}\overline{\bar{\sigma}} \\
\frac{\frac{\sigma}{\omega}}{\omega}\end{array}$ & Benthic & $\begin{array}{l}\text { Subtidal rock } \\
\text { Shallow subtidal sediment }\end{array}$ & & $\begin{array}{l}\text { Shallow sublittoral rock \& biogenic reef } \\
\text { Shallow sublittoral sediment }\end{array}$ & \\
\hline & \multirow{2}{*}{$\begin{array}{l}\frac{ \pm}{\Phi} \\
\frac{5}{\omega}\end{array}$} & Pelagic & & & Shelf waters & \multirow[b]{2}{*}{ Shelf } \\
\hline & & Benthic & Shelf subtidal sediment & & $\begin{array}{l}\text { Shelf sublittoral rock \& biogenic reef } \\
\text { Shelf sublittoral sediment }\end{array}$ & \\
\hline & \multirow[b]{2}{*}{ 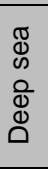 } & Pelagic & & & Oceanic waters & \multirow[b]{2}{*}{ Open ocean } \\
\hline & & Benthic & Deep sea habitats & & $\begin{array}{l}\text { Bathyal rock \& biogenic reef } \\
\text { Bathyal sediment } \\
\text { Abyssal rock \& biogenic reef } \\
\text { Abyssal sediment }\end{array}$ & \\
\hline
\end{tabular}

\section{Assessment and Appraisal Mechanisms}

There is no single, universal methodology through which the natural capital approach is applied, but the core requirement is to measure the extent, status and value of natural capital assets and the services and benefits derived from them (Natural Capital Coalition, 2016; Natural Capital Committee, 2017). This information then provides the baseline against which the impacts of management and development options can be evaluated in the context of defined objectives for environmental exploitation, protection, maintenance and restoration. There are a number of opportunities for implementing the natural capital approach in the context of UK policy (Figure 2), through distinct mechanisms that are based on assessment of either the condition (in ecological terms) of assets and services or the value of goods and benefits (or services that serve as a proxy for these). 


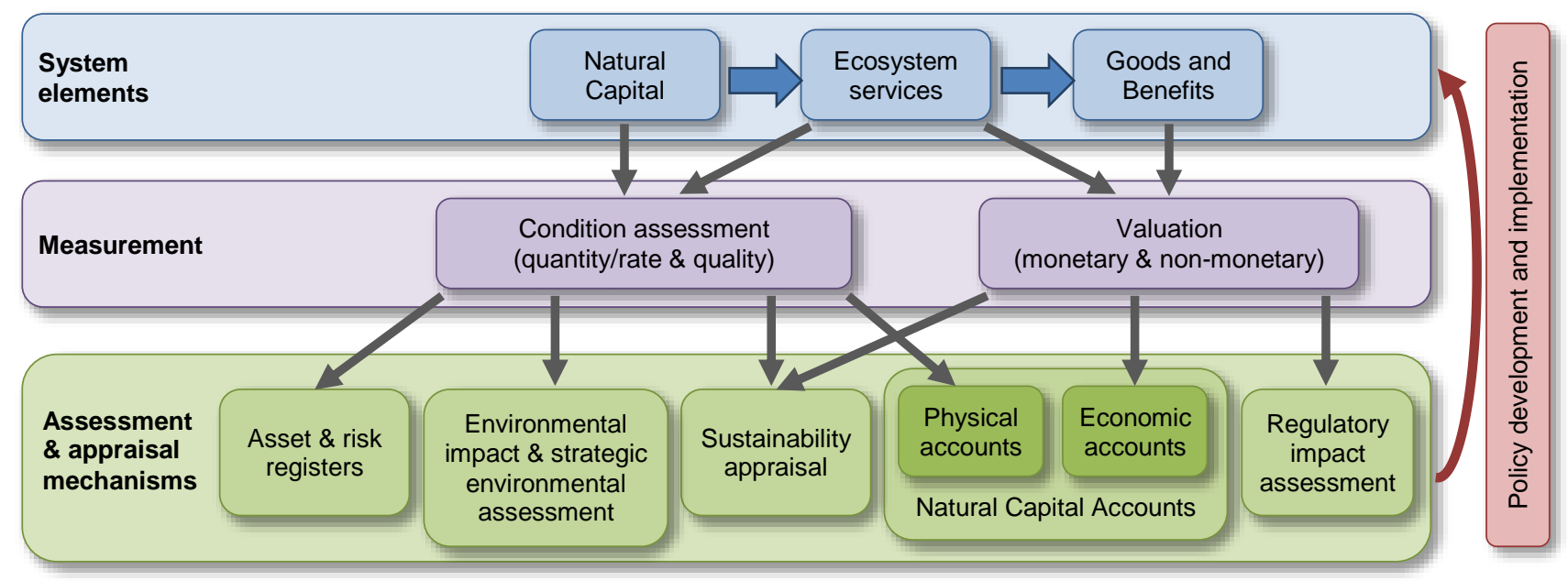

Figure 2. Mechanisms for implementation of the natural capital approach within the UK policy framework

\subsection{Asset register}

An asset register has been defined simply as "an inventory of the natural assets in an area and their condition", for which assets could be defined according to their type, area and quality, using maps and Geographical Information System (GIS) layers where possible (Natural Capital Committee, 2017). The location of an asset and how it is configured (for example the extent of fragmentation) is also important, as this can have a significant effect on ecological functions and on benefits (Mace et al., 2015; Bateman et al., 2011). The Natural Capital Committee (2017) provides guidance on (although not a formal methodology for) developing an asset register. MAES has developed a framework (Erhard et al., 2016), which illustrates how data and maps on habitat extent, condition, ecosystem services and the drivers and pressures by which they are affected can be brought together in the mapping and assessment of ecosystem condition.

Other initiatives for assessing the condition of natural capital have proposed and applied methods that are more quantified and systematic. The Scottish Government first published its Natural Capital Asset Index (NCAI) in 2011, in what was reportedly the first example of a detailed attempt to measure annual changes in natural capital at the national level (Albon et al., 2014). The NCAI (which is reported as a single figure) uses habitats as service providing units (SPUs) and considers their area, their potential to deliver ecosystem services and the relative national importance of these services (assigned primarily through expert judgement), together with indicators of asset condition, in order to model their contribution to human well-being, which is monitored annually relative to the year 2000 (Scottish Natural Heritage, 2018a, 2018b). Pilots and frameworks for natural capital asset indices were also developed for the Netherlands (ten Brink et al., 2003) and Costa Rica (Barton et al. 2014), although these do not appear to have been replicated. Examples of natural capital asset registers can also be found for 
smaller scales, such as that for the Exmoor national park (Deane and Walker, 2018) and the North Devon Marine Pioneer (Rees et al., 2018).

The MAES initiative included a pilot assessment for marine ecosystems (as one broad category) at the EU level (Erhard et al., 2016). Marine habitats do not form part of the NCAI, although it does cover coastal habitats above the spring high tide limit which are normally only affected by spray or splash (coastal dunes and sandy shores (incorporating machair); coastal shingle; and rock cliffs, ledges and shores). A scoping study on the feasibility of a marine NCAI for Scotland has very recently been published (Tillin et al., 2019). It has also been reported that the initial structure for a marine natural capital asset register for UK offshore waters is in development (JNCC, 2018).

\subsection{Risk register}

The Natural Capital Committee (2013) suggests that the assets at greatest risk from unsustainable use and poor management should be identified in order to prioritise natural capital investment decisions. A regularly updated risk register that systematically documents the threats to assets and benefits is proposed as an important tool for this process. A risk register should document the likelihood of changes in the delivery of benefits and the scale of impact of such changes (Natural Capital Committee, 2017). A methodology for developing a risk register, and a preliminary high level assessment at the national scale, was developed by Mace et al. (2015) as part of the Natural Capital Committee's work. Mace et al. (2015) defined their natural asset classes by following the UK NEA (2011) broad habitat types, which include two marine categories: coastal margins and marine (Table 1).

As yet, the development of risk registers for natural capital does not appear to be common practice, although one further example was identified. Lovett et al. (2018) broadly replicated the approach taken by Mace et al. (2015) in developing a risk register for the Anglian Water Combined Services Area, again reporting only for the same broad-scale, aggregated coastal and marine habitats.

\subsection{Natural Capital Accounts}

The accounting element of the natural capital approach has been the focus of significant effort in response to national and international policy drivers. Broadly, the accounting framework includes assessment of both stocks and flows, in monetary and non-monetary terms. Physical accounts consider the extent and quality of stocks, and quantities (rather than values) of ecosystem services and thus overlap with concepts of a natural capital asset registers and condition assessment. There is a distinction in that the expectation with accounts is that these parameters would be quantified and recorded at regular intervals (usually annually).

The United Nations has led efforts to meet commitments for integrated accounts through the System of Environmental-Economic Accounting (SEEA) and the complementary Experimental Ecosystem 
Accounting (EEA), which broadens the perspective to consider ecosystem services and the relationship between stocks and flows (United Nations, 1993; United Nations et al., 2014a,b). The World Bank-led Wealth Accounting and Valuation of Ecosystem Services (WAVES) (Vardon et al., 2017) is a global partnership that aims to mainstream natural resources into development planning and national accounts. However, it contrasts with the SEEA in seeking a shift in emphasis from 'supply side' generation of accounts (technical focus) to 'demand side' support for decision makers in improving natural capital policy (decision-centred focus). At the EU level, the Knowledge Implementation Project on the Integrated system for Natural Capital and ecosystem services Accounting (KIP-INCA) is an ongoing programme that seeks to produce physical and monetary accounts for the $\mathrm{EU}$, and has close links to the MAES initiative and CICES (European Commission \& European Environment Agency, 2016). In the UK, the Office for National Statistics (ONS) recently published experimental ecosystem service accounts for the period 1997 to 2015 (ONS, 2018).

In addition to national-level accounts, the Natural Capital Committee (2013) also advocates corporate natural capital accounting to support understanding amongst businesses, land owners and land managers of the risks to their supply chains and future growth opportunities from the deterioration of natural capital. This has similarities with the Natural Capital Protocol, a framework for decision making at the organisation level that has been developed through an international collaboration (Natural Capital Coalition, 2016).

In the EEA, proposed assessment of stocks is spatial and based on land cover types as defined in the Food and Agriculture Organisation Land Cover Classification System (FAO, 2009) within which there is the single category of coastal water bodies. An early case study involved developing the approach for fisheries (United Nations \& Food and Agriculture Organization of the United Nations, 2004), in an attempt to address the limitation within the existing international System of National Accounts that fish stocks were recorded only in terms of income and did not record stock depletion (and hence potential over-exploitation). The UK's ecosystem service accounts included marine examples through wild caught fish and recreation, although marine and coastal habitats were excluded from the carbon accounts (ONS, 2018). This is in contrast to SEEA carbon accounts for the Netherlands, which did include coastal dunes and saltmarsh (Statistics Netherlands and Wageningen University, 2017). Beyond Europe, the Australian Bureau of Statistics (ABS, 2017) has produced experimental accounts for the Great Barrier Reef area, again based on SEEA-EEA. Accounts for marine and coastal resources are notably lacking from the examples provided in WAVES reporting, which gives only brief reference to those for fisheries and aquaculture in Guatemala (Castaneda et al., 2017) and pilots and scoping studies in the UK and Sweden (Barter, 2017; Steinbach, 2017), although the expectation for these to be included in the future was noted, at least for Costa Rica (Gutiérrez-Espeleta, 2017).

Scoping for marine (eftec, 2015) and coastal margin (ONS, 2016) accounts for the UK provided initial exploratory monetary accounts for carbon sequestration and recreation, fish (marine study only), and sea defence and air quality regulation (coastal margin study only). The set of specified habitats was 
also limited and again used the UK NEA (2011) habitat classification for coastal margin habitats. Saltmarsh also featured in the marine scoping study, together with offshore sediments in two depth ranges, maerl beds, and a general marine category. The marine study also considered the role of the water column in terms of calculating the value of the North Sea carbon pump (an interaction between the North Sea and deeper North Atlantic waters) to carbon sequestration. In exploring ecosystem accounts for UK protected areas, White et al. $(2015 a, b)$ excluded marine habitats but did include limited coastal margin habitats (supralittoral rock and sediment, and saltmarsh) with monetary values reported for assets and services related to livestock (through grazing), air quality, climate regulation and recreation.

At the European level, a horizon scanning exercise has been carried out to establish priorities for marine natural capital accounts (Weatherdon, 2018). This was undertaken primarily from the perspective of integrating ecological information collected as part of EU policy obligations into extent and condition accounts rather than from the perspective of reporting economic values. Related work within the KIPINCA project has developed an experimental seagrass account which aligns with existing habitat classification systems as well as the CICES classification for ecosystem services (Weatherdon et al., 2017). This focused on the extent and condition components, while also noting the contribution of seagrass to certain ecosystem services, namely carbon sequestration, food provisioning, water flow stabilisation, nurseries for commercial fish, and mass stabilisation and erosion control. Marine natural capital accounts for the Dutch North Sea area have also been scoped but not trialled (Graveland et al., 2017).

Examples of pilot corporate natural capital accounts are also emerging. Again, these are largely terrestrial and tend to concern forests or urban green space (e.g. Forest Enterprise England, 2017; eftec \& Jon Sheaff and Associates, 2017; Vivid Economics, 2017). However, one example focussed on a utility company and its maintenance of four designated bathing waters (eftec et al., 2015), while the account compiled for the RSPB (2017) included extent and population trend data for marine and coastal habitats and species, although not explicit monetary values.

\subsection{Policy, Programme and Project Appraisal}

Asset registers, risk registers and accounts are designed as systematic records of status and for reporting changes and trends over time. The natural capital approach also has the potential to support the evaluation of discrete policies, programmes and projects through the adaptation of existing appraisal mechanisms. Policy appraisal and environmental impact assessment are not frameworks specific to natural capital, but do provide key mechanisms through which natural capital information can be incorporated into the wider decision-making process.

\subsubsection{Regulatory Impact Assessment}

The primary appraisal processes for UK national policy is regulatory Impact Assessment (IA), which should not be confused with Environmental Impact Assessment (EIA, discussed in Section 3.4.2). IA is 
used to evaluate the economic, social and environmental implications of new legislation or other policy changes. IAs are also a requirement at the EU level. It has been proposed that the ecosystem service approach fits well with IA because the purpose of the ecosystem service approach is to link the environment to the wellbeing of beneficiaries and so it has the potential to better integrate the three components of IA (Helming et al., 2013).

The EU guidelines make no reference to natural capital and ecosystem services (European Commission, undated). In the UK, the Green Book (HM Treasury, 2018) provides comprehensive, approved guidance, methods and tools for the appraisal process, and makes specific reference to the natural capital framework as a means of enabling "all options to be assessed more accurately for potential improvements and/or damage to the environment." Monetary valuation is central to IA, and the Green Book provides further, brief guidance (and in some cases indicative value estimates) related to valuing specific elements of natural capital, some of which are relevant to in the marine context. There is also a substantial pool of wider resources available to support the monetary valuation that is required in IA, including practitioner guidance on valuation methods (e.g. eftec, 2009, 2010), reviews of monetary valuations (e.g. Torres and Hanley, 2017, specifically for marine and coastal) and value databases (e.g. those held by the Marine Ecosystem Services Partnership, http://map.marineecosystemservices.org/ and the Environmental Valuation Reference Inventory, http://www.evri.ca/).

There is some evidence that at least certain elements of the natural capital approach are applied in practice in IA for the marine environment. The recent IA for designation of the next phase of marine conservation zones in the UK (Defra, 2017) used an ecosystem services framework (from the UK NEA, 2014) to assess the benefits of designation over the baseline option for non-use values, research and education, fish and shellfish for human consumption, natural hazard protection, environmental resilience, gas and climate regulation, and regulation of pollution, and included some monetary values of the benefits arising.

The second main assessment mechanism for national policy is the development of business cases to justify spending proposals. Where explicit reference to natural capital is made within the Green Book (HM Treasury, 2018), this is primarily in the context of determining how policy decisions will impact upon it and not in terms of developing business cases (although this latter mechanism is part of the wider Green Book guidance). The Natural Capital Committee (2013) provided a more specific focus on the use of the natural capital approach in justifying investment decisions, which included a generic framework with the steps required to develop a natural capital investment programme, as well as specific case studies for marine and coastal natural capital. These demonstrated that a strong economic case exists for creating saltmarsh to meet coastal defence objectives, and for restoring commercial fish stocks.

\subsubsection{Environmental impact assessment and sustainability appraisal}


Beyond the development of national policy, there are statutory requirements on specific programmes, plans and projects to consider and address their potential impacts on the environment (and in some cases more widely on society and the economy). In the UK, this is through three primary mechanisms: Environmental Impact Assessment (EIA, at the project level), Strategic Environmental Assessment (SEA, for larger-scale programmes or specific industrial sectors) and Sustainability Appraisal (SA, for development plans such as Local Plans and also Marine Plans). These are required under UK law (including the Environmental Assessment of Plans and Programmes Regulations 2004, Planning and Compulsory Purchase Act 2004, and Environmental Assessment (Scotland) Act 2005), which often developed in response to wider EU legislation (particularly the Strategic Environmental Assessment Directive 2001/42/EC and the Environmental Impact Assessment Directive 2014/52/EU).

There is a substantial academic literature on using the ecosystem service approach in assessing environmental impacts with reference to both EIA and SEA (e.g. Geneletti, 2016; Karjalainen et al., 2013; Rozas-Vásquez et al., 2017), which is advocated not least because there is substantial implicit consideration of ecosystem services in the way that ElAs are already carried out (Honrado et al., 2013). Some high level guidance on how practitioners could incorporate ecosystem services into EIA and SEA was also developed through the UK NEA (Scott et al., 2014), and more detailed guidance has been produced by the Scottish Government (2016) for SEA and, outside the UK, the World Resource Institute (2013) for EIA. Guidance developed within the EIA industry in the UK is beginning to use natural capital language, although not yet to provide specific methodological detail (CIEEM, 2016).

Examples do exist of explicit attempts to integrate, to at least some degree, ecosystem services into environmental assessment in coastal and marine contexts. The SEA for offshore energy in the UK (DECC, 2016) makes passing reference to ecosystem services, while Portugal's Integrated Coastal Zone Management Plan went further and identified and compared policy options in terms of their risk or benefit to certain ecosystem services (Partidário, 2010), However, there is no evidence of any significant or systematic use of natural capital and ecosystem services approaches in practice for coastal and marine EIA and SEA.

Sustainability Appraisal (SA) is a formal decision support mechanism with a specific function in land use planning (including coastal and marine) in the UK. This restriction to the UK context perhaps explains the limited academic literature on integrating natural capital. However, sustainability assessment more broadly is considered particularly suitable for the integration of ecosystem service approaches as both inherently consider the interaction between biophysical and socio-economic issues (Geneletti et al., 2015). Published examples of attempts to apply a natural capital approach to SA in practice in local and marine planning are broadly lacking, beyond occasional passing use of the terminology. However, the North Devon and Torridge Local Plan (2014) is one example of a more definite aspiration to embed ecosystem services concepts into the local planning framework, and the SA for the Marine Plan for Northern Ireland (AECOM and ABPmer, 2018) contains a high-level qualitative assessment (based on expert judgment) of changes in ecosystem services. 


\section{Discussion}

Comparative studies often demonstrate the high relative value of the marine and coastal environment both globally (Costanza et al., 1997; de Groot et al. 2012) and at more local levels. In developing protected area accounts, White et al. $(2015 a, b)$ showed that the monetary value per unit area of coastal margins was almost three times that of the next most highly valued habitat type. However, most of the available research, guidance, scoping and pilot studies have a clear bias towards the terrestrial environment. The difficulties in developing natural capital asset registers or condition assessments applicable across all ecosystems are exemplified by Scotland's Natural Capital Asset Index (NCAl). This does not include marine habitats at all, and those considered coastal are found above the spring high tide level. During the scoping phase for the NCAI the possibilities of incorporating Scottish territorial waters including estuaries were explored (Hambrey \& Armstrong, 2010). However, marine habitats were excluded from the published index, with the recommendation that a separate marine index should be produced (Blaney \& Fairley, 2012). A detailed feasibility study for a marine NCAI only took place in 2018 (Tillin et al., 2019) even though the wider NCAl has been published since 2011.

\section{Boundaries for assessments and management}

One issue for applying the natural capital approach in the marine environment is where the boundaries of any assessment should be placed. On the seaward side, the limit of territorial waters (and thus of national jurisdictions) has been proposed in both the UK and the Netherlands (eftec, 2015; Graveland et al., 2017). However, these governance boundaries do not coincide with the ecosystem boundary (eftec, 2015). UK waters, for example, include parts of, but do not encompass entirely, both the North Sea and Celtic-Biscay large marine ecosystems. Thus effective management based on natural capital and ecosystem services will require international cooperation and unified approaches. The aspiration to "maintain and restore ecosystems and their services" is one of the six targets of the European Union's 2020 Biodiversity Strategy (European Commission, 2011), which has been supported by significant attempts to operationalise assessment and accounting frameworks (e.g. Maes et al., 2013, 2018; Erhard et al., 2016; Weatherdon et al., 2017; Weatherdon, 2018). Although the UK is poised for exit from the European Union, it is expected to maintain connection to regional approaches and programmes through other agreements such as the Convention for the Protection of the Marine Environment of the North-East Atlantic (OSPAR).

The location of any landward boundary between marine and coastal areas is also a point of contention. eftec (2015) chose the mean high water mark as the point of differentiation between marine and coastal, while ONS (2016) took a more ecologically-based approach and defined 'coastal' as the six coastal margin habitats listed in the UK NEA (Jones et al., 2011; see Table 1). However, the UK NEA classification is a hybrid of supralittoral (splash zone) and littoral (intertidal) habitats. Also, it includes only two littoral habitats (coastal lagoons and saltmarsh), and the justification for why these were chosen as the "main" coastal habitats (while most littoral habitats such as mudflats, other intertidal sediments and rocky shores were excluded) is not clear. Basing natural capital assessment on a classification that more closely follows a recognised hierarchy such as the European Nature Information System (EUNIS), 
would provide a more robust and systematic basis for the categorisation of what constitutes 'marine' and 'coastal'.

In the UK context, a pragmatic approach would be to designate all supralittoral and littoral habitats as 'coastal', and to include these with terrestrial assessments. The Land Cover Map (CEH, 2017) and Countryside Survey (Maskell et al., 2008) both include supralittoral and littoral rock, sediment and vegetated habitats and so these are already mapped and assessed in the same way as terrestrial habitats. Fully submerged habitats lack this systematic, repeated assessment at the national level. However, littoral habitats are also an integral component of the marine environment. Therefore, the extent and condition of intertidal assets would have to take account of the tidal state (to ensure the full extent of the intertidal was appropriately mapped) and be expanded to reflect the role of the intertidal zone in supporting marine services (such as how saltmarsh serves as a nursery habitat for commercial fish species).

\section{Habitats as Service Providing Units}

The classifications of coastal and marine habitats that have been developed across different natural capital applications to date are generally very coarse, but such broad habitat types are an inadequate representation of natural capital (Mace et al., 2015). One limitation is that broad classifications do not consider different sediment types, and key functional groups of organisms are not represented. For example, mud and sand habitats support different ecosystem services, and subtidal sediments with biogenic habitats such as oyster, worm or mussel reefs function very differently to those without (Potts et al., 2014). The disaggregation of vegetated habitats from broader sedimentary habitats is a step forward (although often only saltmarsh is differentiated, as in, for example, the UK NEA, 2011).

There is a limit to the number of distinct habitats that can be feasibly and cost-effectively considered within natural capital assessments and reporting, although this will vary with the scale and purpose of the assessment. However, vegetated habitats and biogenic reefs (intertidal and subtidal) are essential habitats that should be included as distinct categories given the elevated ecosystem services they tend to provide (Potts et al., 2014). In the development of frameworks, efforts by EU agencies have tended to be focused towards the more ecological components of natural capital, while the UK has had a stronger focus on the monetary component. The habitat classification in the EU MAES programme (Maes et al., 2013) is the most systematic in its selection of the broad habitat categories, and it does include biogenic reefs, although it lacks explicit disaggregation of vegetated habitats. MAES is also unique in considering pelagic habitats alongside benthic, with different salinities differentiated, as well as different marine zones (e.g. coastal, shelf and oceanic). This is fundamental to an adequate habitat classification framework; it begins to acknowledge the role of the water column in the supply and distribution of services.

The use of defined, discrete, spatially-bound habitats as SPUs illustrates the way in which the natural capital approach has developed primarily from land cover assessment in the terrestrial environment and it does not recognise certain key aspects of marine systems. In particular, large numbers of species 
(from plankton to whales) move horizontally and vertically through the water column on different spatial and temporal scales and may use different habitats (benthic and pelagic) for different phases of their lifecycle. Also, not all environmental change manifests in relation to changes in spatial extent, not least because the spatial area of many marine habitats (aside from biogenic or vegetated habitat types) generally does not vary greatly. Temporal factors are also important. Phytoplankton, for example, have a seasonal succession of blooms, which historically have been matched to seasonal succession of higher species that could consume them, including larval fish of commercial importance and small fish important for seabirds. Climate change is affecting the timing of blooms, which is reducing the productivity and survival of some fish and bird species in UK waters (Edwards and Richardson, 2004). These issues may be particularly apparent as challenges for the marine environment, but they are relevant to terrestrial systems, which also support migratory species (particularly birds) and face issues of how phenology might be affected by climate change.

As yet, however, the natural capital approach does not adequately account for these factors, and determining mechanisms by which it can do so is an important area for further research. At its simplest, this would require that extent and condition assessment is extended to populations of key species (including plankton, fish, marine megafauna and seabirds). Recent definitions are explicit in their inclusion of "natural functions and processes" as a fundamental component of natural capital (Natural Capital Committee, 2017). This needs to be put into practice to ensure that the natural capital approach to habitat assessment takes account of the roles played in supporting mobile species, particularly at key life cycle stages. Future research should therefore consider what is already known about populations of mobile species (fisheries management, for example, already includes the regular monitoring, mapping and modelling of mobile stocks) and also how ecosystem approaches such as essential fish habitat (e.g. Rosenberg et al., 2000) can be brought into the natural capital approach. Culhane et al. (2018) have recently begun to address the issue of the interaction of mobile species and the benthos by proposing SPUs that consider how biotic groups and habitats combine in the provision of ecosystem services. Wider approaches to three dimensional mapping of marine ecosystems, although not in the specific context of natural capital, are also being explored such as the ecological marine units approach of Sayre et al. (2017).

\section{Moving from aspirations to widespread adoption}

At present, the natural capital approach is supported by aspirations contained within policy documents but its use is rarely mandated in any decision-making process. This lack of obligation is likely to affect uptake of the approach in practice. The most significant progress has been made in creating natural capital accounts, reflecting, in the UK, the specific commitment made in the Natural Environment White Paper (HM Government, 2011) and the subsequent focussed efforts by UK government agencies (through the Office for National Statistics and the Department for the Environment Food and Rural Affairs) to develop practical methodologies. The Scottish Government has similarly adopted "Increase natural capital" as one of 55 National Indicators which document progress towards achieving the 
Scottish Government's ambition and priority outcomes (Scottish Government, 2018), thus enshrining their Natural Capital Asset Index (in at least some form) as an assessment mechanism.

Such explicit commitments have not been made in regard to other mechanisms through which the natural capital approach could be implemented, perhaps explaining why these options for the approach have not been taken up. The procedures for Environmental Impact Assessment (EIA) are heavily regulated, but these regulations do not make reference to natural capital despite recent attempts to begin to include the language. During revision of the European Union's EIA Directive 2011/92/EU, the text for proposed amendments explicitly included the requirement that the effects of a project on ecosystem services were assessed (European Commission, 2012), but this was not taken forward in the final amendments adopted for the revised Directive 2014/52/EU. In other sectors, attempts have been made to ensure that a natural capital approach becomes mandatory. Since 2012, recipients of funding from the International Finance Corporation (part of the World Bank Group and focussing exclusively on the private sector in developing countries) have been required to "preserve the benefits from ecosystem services" and thus integrate ecosystem services into project impact assessments (World Resources Institute, 2013).

\section{Data gaps and limitations on using existing approaches in the marine environment}

The lack of marine examples does not mean that frameworks and proposed methods are not fit for purpose. However, it does mean that it is not possible to evaluate them comprehensively in the marine context. The development of monetary natural capital accounts has provided the greatest number of marine and coastal examples. Certain habitats and services (fisheries, carbon sequestration, recreation, saltmarsh, sea defence, and, in the global context, seagrass and coral reefs) have featured most frequently in scoping studies and pilot accounts to date (e.g. eftec, 2015; ONS, 2016; White et al., 2015a,b; Weatherdon et al., 2017; ABS, 2017). This is presumably because they are the most straightforward (due to the greater availability of supporting research), potentially of particular policy significance, and most amenable to the direct transfer of terrestrial approaches, as well as because condition indicators are already available that can be re-purposed easily for natural capital assessment. There is a pressing need to explore how other services (including regulating services such as bioremediation of waste and the less tangible elements of cultural services including heritage and indirect interactions) as well as marine, rather than coastal, components could be incorporated for different policy contexts and scales. Using methods not related to habitat extent are likely to be required for this, and it could be misleading solely to estimate the value of relatively trivial services simply because they have the best data and ignore more important services where valuation is more challenging (eftec, 2015). The availability of empirical valuation data is often driven by existing markets and powerful economic interests, and so a better understanding of the links between ecosystem services and human wellbeing (including through the expansion of social assessments) is required to ensure that sufficient valuation data is available to support management recommendations (Hicks, 2011). 
The availability of data is a key challenge, particularly in the marine environment, as was highlighted across studies that have scoped different elements of the natural capital approach. The lack of annual data was highlighted as the main weakness for marine indicators in Scotland's NCAI (Hambrey \& Armstrong, 2010). Inconsistent data collection across most marine species groups was a similar issue for the development of a risk register (Mace et al., 2015), and carbon sequestration from marine ecosystems including intertidal areas was not included in the UK national carbon accounts due to data constraints (ONS, 2016). Four marine ecosystem types were proposed in the MAES typology (namely marine inlets and transitional waters, coastal, shelf, and open ocean) but, during pilot studies to test the approach, these were aggregated into a single, high-level 'marine' assessment due to a lack of data (Erhard et al., 2016). Only two (of seven) terrestrial categories were similarly combined. At a more local level, the issue of data availability was raised repeatedly within pilot marine natural capital accounts and scoping studies. Flood protection and erosion control were considered difficult to account for due to context specificity (eftec, 2015; RSPB, 2017; White et al., 2015b). More generally for the marine environment, the absence of spatial and/or time series data, as well as the lack of understanding of the links between extent, condition and the value of benefits was noted (eftec, 2015; ONS, 2016; Weatherdon, 2018; Weatherdon et al., 2017).

Even more fundamentally, there is a lack of confidence in the baseline data that can inform on the extent of natural capital assets; outside of designated sites the only available data are often modelled predictions, or stock assessment surveys designed to provide data on commercial fish (Rees et al., 2018). In the UK marine area, for example, high quality habitat maps from surveys are only available for $6 \%$ of the seabed (McBreen et al., 2010), illustrating the heavy reliance on modelled maps. The modelled habitat maps across European seas use physical and oceanographic parameters to predict likely habitat types (Populus et al., 2017) and are thus particularly limited for condition assessment. Furthermore, the condition of many marine ecosystems is unknown, and where information does exist it may not be sufficiently geo-referenced to allow mapping (Erhard et al., 2016). This considerable information gap between spatial assessments of marine and terrestrial ecosystem services is widely acknowledged (Liquete et al., 2013). The situation is better within marine protected areas where detailed data are more likely to be available as the extent of features has previously been surveyed and condition assessments are undertaken periodically (but rarely annually) for designated habitats and species features (Rees et al., 2018).

It is impractical to suggest significant new research programmes to map and monitor changes in natural capital and ecosystem services at the national level, much as these would be desirable, as the investment that would be required to do so with adequate confidence and regularity is likely to be prohibitive. Alternative approaches are therefore needed, including understanding how the data collected under existing programmes can be used to support natural capital assessment. The possibility of integrating key indicators used for existing policy purposes, such as the Habitats, Birds, Water Framework and Marine Strategy Framework Directives, into ecosystem service monitoring has been piloted (Erhard et al., 2016; Maes et al., 2018). The MSFD 'Good Environmental Status' requirements 
were also suggested as a starting point for the development of extent and condition indicators in natural capital accounts (Graveland et al., 2017; Weatherdon, 2018).

In the absence of direct extent and condition data, the use of proxies, particularly pressure indicators such as abrasion caused by fishing, is a possible alternative solution (eftec, 2015; Weatherdon, 2018), which has considerable potential when combined with sensitivity information. Levels of protection or vulnerability (e.g. European Red List designation) have also been suggested as possible proxies (Weatherdon et al., 2017; Weatherdon, 2018). Models have been proposed as a means to fill certain evidence gaps (eftec, 2015; European Commission \& European Environment Agency, 2016; Weatherdon et al., 2017), although the accuracy of process-based models has been questioned (eftec, 2015). Modelling was not considered a fully adequate replacement for in situ data and hence of limited application in long-term accounts (Weatherdon et al., 2017). The role of remote sensing was also identified (European Commission \& European Environment Agency, 2016). Remote sensing has the potential to provide cost effective information on key pelagic indicators such as primary productivity, sea surface temperature, and occurrence of harmful algal blooms, and also to monitor the quality and quantity of coastal and intertidal habitats. Its use in monitoring sublittoral benthic habitats remains limited.

In addition to the evidence gaps related to ecological data, the lack of monetary values for many marine goods and services has been highlighted as a challenge that inhibits the use of ecosystem service values to support policy decisions, for example in the context of marine planning (Borger et al. 2014). The Impact Assessment for Marine Conservation Zones (MCZs; Defra, 2017) included monetary values of certain benefits for "illustrative purposes" but for reasons of uncertainty, values for the benefits were not presented in the overarching summary and were not compared with costs of designation. Thus, in the headline figure of the Impact Assessment, MCZ designation has a negative value overall.

The level of evidence required depends on the decision context: simply raising awareness may be sufficient without needing monetary valuation, and high level information can be enough for developing national policy. However, evidence requirements become more stringent when specific decisions are made (such as in restricting certain activities) as these may be open to legal challenges. Scenarios of different risks and model outputs have a role as tools to support decision making but policy makers and managers need to be clear about what evidence is required and how much uncertainty is acceptable.

\section{Institutional inertia and poor practice}

An advantage of the natural capital approach is that it provides a holistic process that can employ broad information in making the case for a policy intervention. However, its application in practice may face obstacles, not all of which stem from the approach itself. The UK NEA Follow-On phase noted the critical role of policy appraisal in incorporating ecosystem knowledge in the policy process (Russel et al., 2014). It also highlighted that there are significant barriers to embedding an ecosystem services framework within appraisal at all scales from practitioner behaviour, institutional culture and practice, to 
the wider social and political context (Russel et al., 2014). There is also often a disconnect between those managing and using ecosystem services and those managing the underlying natural capital that ensures their delivery. The partitioning of fisheries from wider marine environmental management is a prime example of this.

Regardless of whether it is applied in a natural capital context, regulatory Impact Assessment should incorporate economic, environmental and social information, and guidance exists on how to take appropriate account of non-monetary factors (e.g. HM Treasury, 2018). Thus, the lack of robust quantified evidence for marine natural capital, and particularly the absence of a full suite of monetary values, should have only limited implications. However, half of 249 Impact Assessments fitting sustainable development criteria ignored or undertook inadequate treatment of social and environmental impacts, while only $16 \%$ were judged to have treated economic information with similarly low rigour (Tinch et al., 2014). Practitioners themselves agreed that environmental and social impacts that are not monetised are underweighted or overlooked in appraisal (Tinch et al., 2014). A cultural shift is therefore required to ensure that non-monetary values and qualitative information is appropriately incorporated, which could be supported by stronger guidance, as has already been recommended by the National Audit Office (2011). Appraisal is often led by economists, and improved interdisciplinary working also has the potential to allow for better integration of non-monetary information (Spackman, 2013).

\section{Application in the global context}

This review has focused on the UK, as the current policy landscape makes for a particularly timely case study. However, progress (directly and indirectly) on developing the natural capital approach for marine ecosystems is taking place globally, including through efforts to classify and map seabed habitats and to increase the availability of this data, such as in Australia (CBiCS, 2019; Lucieer et al., 2017), South Africa (South African National Biodiversity Institute, 2011), and the United States (NOAA, undated). The National Classification Systems for Ecosystem Services (NCSES) has also been developed in the United States, which incorporates the demand side and links more closely to national classifications of industrial activity, and is intended particularly to support policy impact analyses including cost-benefit analysis of environmental regulations, and accounting systems (United States Environmental Protection Agency, 2015).

In addition to the examples of specific developments in natural capital accounts already described in Section 3.3, a workshop on developing an accounting system for marine ecosystems at the EU level concluded that the SEEA-EEA process, with some modification, could be applied to marine systems, and that pilot accounts and case studies should be developed to move forward with the approach (Petersen, 2017). The workshop further highlighted the challenges presented by the three dimensional nature of the marine environment and the mobility of species, as well as the need for investment in data 
collection to allow more detailed and convincing marine ecosystem accounts to be developed (Petersen, 2017).

A workshop on developing ocean accounts for Asia and the Pacific region was also held in late 2018, which was convened in the context of implementation of the UN Sustainable Development Goal (SDG) 14 on the conservation and sustainable use of the oceans and marine resources. The role of natural capital accounts in strategies for SDG14 has been proposed elsewhere (Ruijs et al., 2018), with possibilities for the approach in underpinning actions on SDGs more widely also proposed (Costanza et al., 2016; Wood et al., 2018). The intersection of the natural capital and sustainable development concepts is further explored within the first World Ocean Assessment (or Global Integrated Marine Assessment; United Nations Division for Ocean Affairs and the Law of the Sea, 2016). The framing of this assessment shares much with the natural capital approach, including the desire to (a) Demonstrate the importance of oceans to human life and as a component of the planet; and (b) Integrate, analyse and assess environmental, social and economic aspects of all oceans components and interactions among all sectors of human activity affecting them; as well as to promote well-designed assessment processes, and support better decision-making in policy and management.

The World Ocean Assessment (from 2016) advocates an ecosystem services approach, but considers biodiversity and habitats, and also human activities separately from this. Future revisions would perhaps benefit from integrated application of the wider natural capital approach, to provide a more holistic framework for the complete assessment. The outline for the second assessment calls for descriptions of changes related to concepts of natural capital, in the context of social and economic implications, to be included within each chapter of the assessment (United Nations, 2018). However, there is greater scope for other elements of the natural capital approach to be applied, using, for example, asset and risk registers in reporting the status and trends of marine assets.

Other international programmes dedicated to natural capital and ecosystem service assessment have also increased activity in developing frameworks and protocols specifically for the marine environment. The Economics of Ecosystems and Biodiversity (TEEB) has had an ongoing Oceans and Coasts study for some years (TEEB, 2013), although this does not appear to have produced recent outputs. Information on coastal and marine areas is included within regional assessments prepared by the Intergovernmental Science-Policy Platform on Biodiversity and Ecosystem Services (e.g. IPBES, 2018), which has also stated its intention to conduct an assessment of the Open Ocean areas beyond national jurisdictions (IPBES, 2015). At a smaller scale, the Natural Capital Coalition has also begun work on a Natural Capital Protocol for the Oceans to help businesses improve economic opportunities, mitigate risks and reduce negative impacts (Natural Capital Coalition, 2018).

These initiatives all have their own objectives, methods, and audiences, and there remains scope to improve linkages between different international programmes, and the individual projects occurring at regional, national and local scales. This would provide the opportunity to better understand how these 
different programmes connect to each other and to develop a framework and best practice that can be applied universally to facilitate nested approaches and compare individual studies.

\section{Conclusions}

Application of the natural capital approach requires a range of methods and procedures, which as yet have not been fully tested in the context of decision making for the marine environment, even for natural capital accounts on which most attention has been focused. Greater effort to develop methodologies is therefore required, which should be interdisciplinary and cross-sectoral, coherent across policy areas, and applicable in a range of contexts.

There are substantial challenges in applying the natural capital approach: data for the marine environment are inconsistent, there are significant gaps in understanding how habitats and species support the delivery of ecosystem services, and knowledge of the location and extent of habitats across most of the marine area is highly uncertain. A system of natural capital assessment based on the quality and quantity of marine benthic habitats (i.e. following terrestrial land cover strategies) is therefore unworkable in practice at the national level. Alternative methods that use proxies for quality information (based on, for example, known pressures and habitat sensitivity) as well as the opportunities for remote sensing should be explored further. A natural capital approach that more closely follows existing terrestrial strategies in making more direct assessment of the extent and condition of marine benthic habitats has greater potential at smaller spatial scales, such as for an individual protected area.

More generally, it is essential that the service providing units that constitute the foundation of natural capital assessment are selected appropriately. Here again, the terrestrial land cover approach as currently adapted for the marine environment is inadequate. Benthic habitat classifications should be further disaggregated to ensure vegetated habitats and biogenic reefs are adequately assessed. Most importantly, natural capital classifications must include the pelagic environment and must also encompass the interconnections between spatially disparate components, and the dynamic nature of the system, for example the spatial mobility of many species as well as temporal factors. This is a major omission from, and also a real challenge for, frameworks for marine natural capital. Future research should therefore evaluate the mechanisms for monitoring, mapping and modelling populations of pelagic species as well as how existing whole system approaches (including concepts such as essential fish habitat) can be recognised explicitly within the natural capital approach.

Finally, when the adoption of a natural capital approach has been promoted, there has been a tendency to focus on the aspect of monetisation. For the approach to be applied effectively, impacts on the quality and quantity of natural capital assets and on non-monetary values need to be given the same level of attention as impacts on monetary value. The real strength of the natural capital approach is in its potential for implementation as a coherent whole, not through the isolated application of individual elements of it. There is, therefore, a need for convergence around frameworks and methods for applying 
the natural capital approach in practice that ensures coherence between different assessments and across different scales. This could include, for example, adopting asset and risk registers as the baseline for environmental impact assessment at strategic and project scales, and choosing ecological indicators that can be applied in accounting contexts.

\section{Acknowledgments}

This work was funded by the UK Department for the Environment, Food and Rural Affairs (project ME5115) and also by the Natural Environment Research Council through the South West Partnership for the Environment and Economic Prosperity (SWEEP; grant NE/P011217/1).

\section{References}

ABS (Australian Bureau of Statistics). (2017). Experimental environmental-economic accounts for the Great Barrier Reef. Canberra, Australia.

AECOM and ABPmer. (2018). Marine Plan for Northern Ireland - Sustainability Appraisal. Volume 2: Sustainability Appraisal Report. Report for the Northern Ireland Department for Agriculture, Environment and Rural Affairs

Agriculture Bill. (2018). Bill 266 2017-2019. As introduced on 12 September 2018. https://services.parliament.uk/Bills/2017-19/agriculture/documents.html (Accessed 5 November 2018)

Albon, S., Balana, B., Brooker, R., \& Eastwood, A. (2014). A systematic evaluation of Scotland's Natural Capital Asset Index. Scottish Natural Heritage Commissioned Report No. 751.

Atkins, J., Gregory, A. J., Burdon, D., \& Elliott, E. (2011). Managing the marine environment: Is the DPSIR framework holistic enough? Systems Research and Behavioral Science, 28(5), 497-508. doi:10.1002/sres.1111

Barter, N. (2017). Natural capital policy in the United Kingdom In M. Vardon, S. Bass, S. Ahlroth \& A. Ruijs (Eds.). Forum on natural capital accounting for better policy decisions: taking stock and moving forward. Washington D.C.: World Bank. Wealth Accounting and the Valuation of Ecosystem Services.

Barton, D. N., Kelemen, E., Dick, J., Martin-Lopez, B., Gómez-Baggethun, E., Jacobs, S., ... \& Dunford, R. (2018). (Dis) integrated valuation-Assessing the information gaps in ecosystem service appraisals for governance support. Ecosystem Services, 29, 529-541.

Barton, D.N., G. Certain, S. Chaves, J. Cuadra, A. Herrera, P.Kvaløy, M. A. Mora, S. Nybø, V. Obando, B. Pedersen, J. Ugalde, M. Vargas (2014) Nature Index Costa Rica. An IPBES pilot project- NINA Report 1112. $67 \mathrm{pp}$

Bateman I.J., Mace G.M., Fezzi C., Atkinson G. and Turner K. (2011). Economic Analysis for Ecosystem Service Assessments. Environmental and Resource Economics, 48(2), 177-218

Beaudoin, Y., \& Pendleton, L. (2012). Why value the oceans? A discussion paper prepared by UNEP/Grid-Arendal and Duke University's Nicholas Institute for Environmental Policy Solutions in collaboration with the UNEP TEEB Office and the UNEP Regional Seas Programme. Geneva: The Economics of Ecosystems and Biodiversity.

Beaumont, N., Austen, M. C., Atkins, J. P., Burdon, D., Degraer, S., Dentinho, T. P. et al. (2007). Identification, definition and quantification of goods and services provided by marine biodiversity: Implications for the ecosystem approach. Marine Pollution Bulletin, 54, 253-265.

Beaumont, N., Austen, M. C., Mangi, S. C., \& Townsend, M. (2008). Economic valuation for the conservation of marine biodiversity. Marine Pollution Bulletin, 56, 386-396. 
Blaney, R., \& Fairley, R. (2012). Valuing our ecosystems: Scotland's Natural Capital Asset Index. Agriculture and the Environment IX, Valuing Ecosystems: Policy, Economic and Management Interactions. 8-13.

Böhnke-Henrichs, A., Baulcomb, C., Koss, R., Hussain, S. S., \& de Groot, R. S. (2013). Typology and indicators of ecosystem services for marine spatial planning and management. Journal of Environmental Management, 130, 135-145.

Börger T., Beaumont N., Pendleton L., Boyle K., Cooper P., Fletcher S., Haab T., Hanemann M., Hooper T., Hussain S., Portela R., Stithou M., Stockill J., Taylor T. and Austen M. 2014. Incorporating ecosystem services in marine planning: The role of valuation. Marine Policy 46:161-170

ten Brink BJE, van Hinsberg A., de Heer M, van der Hoek DCJ, de Knegt B] , Knol OM , Ligtvoet W , Rosenboom R , Reijnen MJSM. (2003).Technical design Natural Capital Index framework and implementation for the Nature Outlook 2. RIVM Report 408657007

Castaneda, J.-P., Castillo, F. C., \& Matias, I. (2017). Implementing natural capital accounting in developing countries: public-academic partnerships and policy uptake in Guatemala. In M. Vardon, S. Bass, S. Ahlroth \& A. Ruijs (Eds.), Forum on natural capital accounting for better policy decisions: taking stock and moving forward. Washington D.C.: World Bank. Wealth Accounting and the Valuation of Ecosystem Services.

CBiCS (2019). Combined Biotope Classification Scheme. http://www.cbics.org/ Accessed 19 March 2019

CEH. (2017). Land Cover Map 2015. Dataset Documentation version 1.0, 6 April 2017. Centre for Ecology and Hydrology. https://www.ceh.ac.uk/sites/default/files/LCM2015 Dataset Documentation.pdf Accessed 16 November 2018

CIEEM (2016) Guidelines for Ecological Impact Assessment in the UK and Ireland: Terrestrial, Freshwater and Coastal, 2nd edition. Chartered Institute of Ecology and Environmental Management, Winchester

Costanza, Robert, Lew Daly, Lorenzo Fioramonti, Enrico Giovannini, Ida Kubiszewski, Lars Fogh Mortensen, Kate E. Pickett, Kristin Vala Ragnarsdottir, Roberto De Vogli, and Richard Wilkinson. "Modelling and measuring sustainable wellbeing in connection with the UN Sustainable Development Goals." Ecological Economics 130 (2016): 350-355.

Costanza, R. (2008). Ecosystem services: Multiple classification systems are needed. Biological Conservation, 141, 350-352.

Costanza, R., d'Arge, R., De Groot, R., Farber, S., Grasso, M., Hannon, B. et al. (1997). The value of the world's ecosystem services and natural capital. Nature, 387(6630), 253-260.

Culhane, F. E., Frid, C. L., Royo Gelabert, E., White, L., \& Robinson, L. A. (2018). Linking marine ecosystems with the services they supply: what are the relevant service providing units?. Ecological Applications, 28(7), 1740-1751.

de Groot, R., Brander, L., van der Ploeg, S., Costanza, R., Bernard, F., Braat, L. et al. (2012). Global estimates of the value of ecosystems and their services in monetary units. Ecosystem Services, $1(1), 50-61$.

de Groot, R., Wilson, M. A., \& Boumans, R. M. J. (2002). A typology for the classification, description and valuation of ecosystem functions, goods and services. Ecological Economics, 41, 393-408.

Deane R and Walker A (2018). Towards a Register of Exmoor's Natural Capital. Report to the Exmoor Society, Dulverton.

DECC. (2016). UK Offshore Energy Strategic Environmental Assessment. OESEA3 Environmental Report Future Leasing/Licensing for Offshore Renewable Energy, Offshore Oil \& Gas, Hydrocarbon Gas and Carbon Dioxide Storage and Associated Infrastructure. March 2016. Department for Energy and Climate Change.

Defra. 2017. : Designation of the third tranche of Marine Conservation Zones IA No: Defra/MAR/008 RPC Reference No: RPC17-DEFRA-4197(1). 11 December 2017. 
https://consult.defra.gov.uk/marine/consultation-on-the-third-tranche-of-marineconser/supporting documents/Impact\%20Assessment.pdf Accessed 12 November 2018.

Dickie, I., Cryle, P., \& Maskell, L. (2014). UK National Ecosystem Assessment Follow-on. Work Package Report 1: Developing the evidence base for a Natural Capital Asset Check: What characteristics should we understand in order to improve environmental appraisal and natural income accounts? UK: UNEP-WCMC LWEC.

Edwards, M., \& Richardson, A. J. (2004). Impact of climate change on marine pelagic phenology and trophic mismatch. Nature, 430(7002), 881.

eftec (economics for the environment) (2015). Developing UK Natural Capital Accounts: Marine Scoping Study. Report for the Department for Environment, Food and Rural Affairs. 124pp.

Eftec. (2010). Flood and Coastal Erosion Risk Management: Economic Valuation of Environmental Effects. Handbook for the Environment Agency for England and Wales Revised March 2010. https://assets.publishing.service.gov.uk/government/uploads/system/uploads/attachment data/fil e/487240/LIT 10352.pdf Accessed 13 November 2018

Eftec. (2009). Valuing Environmental Impacts: Practical Guidelines for the Use of Value Transfer in Policy and Project Appraisal. Value Transfer Guidelines Submitted to Department for Environment, Food and Rural Affairs 2009, https://assets.publishing.service.gov.uk/government/uploads/system/uploads/attachment data/fil e/182376/vt-guidelines.pdf Accessed 13 November 2018

eftec (economics for the environment) \& Jon Sheaff and Associates. (2017). London Borough Of Barnet Corporate Natural Capital Account. 39pp. https://www.eftec.co.uk/project/\%20\%09londonborough-barnet-corporate-natural-capital-account

eftec (economics for the environment), RSPB (Royal Society for the Protection of Birds), \& PwC. (2015). Developing corporate natural capital accounts. Final report for the Natural Capital Committee. 80pp.

https://assets.publishing.service.gov.uk/government/uploads/system/uploads/attachment data/fil e/516968/ncc-research-cnca-final-report.pdf

Erhard, M., Teller, A., Maes, J., Meiner, A., Berry, P., Smith, A. et al. (2016). Mapping and assessment of ecosystems and their services. mapping and assessing the condition of Europe's ecosystems: Progress and challenges. Luxembourg: Publications office of the European Union.

European Commission (2012). Proposal for a DIRECTIVE OF THE EUROPEAN PARLIAMENT AND OF THE COUNCIL amending Directive 2011/92/EU on the assessment of the effects of certain public and private projects on the environment. Brussels, 26.10.2012 COM(2012) 628 final 2012/0297 (COD). https://eur-lex.europa.eu/legalcontent/EN/TXT/PDF/?uri=CELEX:52012PC0628\&qid=1542029800741\&from=EN Accessed 12 November 2018

European Commission (2011). The EU Biodiversity Strategy to 2020. European Commission Publications Office, Luxembourg. http://ec.europa.eu/environment/nature/info/pubs/docs/brochures/2020\%20Biod\%20brochure\%2 0final\%20lowres.pdf Accessed 16 November 2018

European Commission (undated). Better Regulation Guidelines. Chapter III. Guidelines on impact assessment. https://ec.europa.eu/info/sites/info/files/better-regulation-guidelines-impactassessment.pdf

European Commission \& European Environment Agency. (2016). Report on phase 1 of the knowledge innovation project on an integrated system of natural capital and ecosystem services accounting in the EU (KIP-INCA Phase 1 report).

Everard, M., Jones, L., \& Watts, B. (2010). Have we neglected the societal importance of sand dunes? An ecosystem services perspective. Aquatic Conservation: Marine and Freshwater Ecosystems, 20(4), 476-487.

FAO. (2009). Food and Agriculture Organization of the United Nations (FAO) Global Land Cover Network. Land Cover Classification System v.3 (or Land Cover Meta Language). FAO, Rome. 
Fisher, B., Turner, R. K., \& Morling, P. (2009). Defining and classifying ecosystem services for decision making. Ecological Economics, 68, 643-653.

Fisheries Bill. (2018). HCB 278 2017-2019. As introduced on 25 October 2018. https://services.parliament.uk/Bills/2017-19/fisheries.html (Accessed 5 November 2018)

Forest Enterprise England. (2017). Natural Capital Account 2016-2017. https://www.forestry.gov.uk/pdf/naturalcapitalaccount2017.pdf/\$FILE/naturalcapitalaccount2017. pdf

Geneletti, D. (Ed.). (2016). Handbook on biodiversity and ecosystem services in impact assessment. Edward Elgar Publishing.

Geneletti, D, A Bond, D Russel, J Turnpenny, W Sheate and A Jordan (2015), "Chapter 10: Ecosystem services and sustainability assessment: theory and practice", in A Morrison-Saunders, J Pope and A Bond (editors), Handbook of Sustainability Assessment (Edward Elgar, Cheltenham, UK and Northampton, USA) pages 215-234.

Graveland, C., Remme, R., \& Schenau, S. (2017). Exploring the possible setup and uses of natural capital accounts for the Dutch North Sea area. Final Report. Centraal Bureau voor de Statistiek, Netherland. https://www.cbs.nl/-/media/_pdf/2018/02/nca\%20north\%20sea\%20\%20dcs_version_08.pdf

Gutiérrez-Espeleta, E. E. (2017). Costa Rica: influence of natural resources accounting on public policy and decision making. In M. Vardon, S. Bass, S. Ahlroth \& A. Ruijs (Eds.). Forum on natural capital accounting for better policy decisions: taking stock and moving forward. Washington D.C.: World Bank. Wealth Accounting and the Valuation of Ecosystem Services.

Haines-Young, R., \& Potschin, M. B. (2018). Common International Classification of Ecosystem Services (CICES) V5.1 and Guidance on the Application of the Revised Structure. https://cices.eu/content/uploads/sites/8/2018/01/Guidance-V51-01012018.pdf

Haines-Young, R., \& Potschin, M. (2013). Common International Classification of Ecosystem Services (CICES): Consultation on Version 4, August-December 2012. EEA Framework Contract No EEA/IEA/09/003.: European Environment Agency.

Haines-Young, R., \& Potschin, M. (2010). The links between biodiversity, ecosystem services and human well-being. In D. Raffaelli \& C. Frid (Eds.), Ecosystem Ecology: a new synthesis. Cambridge: Cambridge University Press.

Hambrey, J., \& Armstrong, A. (2010). Piloting a Natural Capital Asset Index. Scottish Natural Heritage Commissioned Report No. 750.

Hattam, C., Atkins, J. P., Beaumont, N., Börger, T., Böhnke-Henrichs, A., Burdon, D. et al. (2015). Marine ecosystem services: linking indicators to their classification. Ecological Indicators, 49, 6175.

Helming, K., Diehl, K., Geneletti, D., \& Wiggering, H. (2013). Mainstreaming ecosystem services in European policy impact assessment. Environmental Impact Assessment Review, 40, 82-87.

HM Government. (2011). The natural choice: securing the value of nature. HM Government Natural Environment White Paper. Presented to Parliament by the Secretary of State for Environment, Food and Rural Affairs by Command of Her Majesty. https://www.gov.uk/government/publications/the-natural-choice-securing-the-value-of-nature

HM Government. (2018). A green future: our 25 year plan to improve the environment. London: Department for the Environment Food and Rural Affairs. https://www.gov.uk/government/publications/25-year-environment-plan

HM Treasury. (2018). The Green Book. Central Government Guidance on Appraisal and Evaluation. London.

Honrado, J.P., C. Vieira, C. Soares, M.B. Monteiro, B. Marcos, H.M. Pereira and M.R. Partidário (2013), 'Can we infer about ecosystem services from EIA and SEA practice? A framework for analysis and examples from Portugal', Environmental Impact Assessment Review, 40, 14-24.

Hooper T., Cooper P., Hunt A. and Austen M. 2014. A methodology for the assessment of local-scale changes in marine environmental benefits and its application. Ecosystem Services 8:65-74 
Hussain, S. S., Winrow-Giffin, A., Moran, D., Robinson, L. A., Fofana, A., Paramor, O. A., \& Frid, C. L. (2010). An ex ante ecological economic assessment of the benefits arising from marine protected areas designation in the UK. Ecological Economics, 69(4), 828-838.

IPBES. (2018). The IPBES regional assessment report on biodiversity and ecosystem services for Europe and Central Asia. Rounsevell, M., Fischer, M., Torre-Marin Rando, A. and Mader, A. (eds.). Secretariat of the Intergovernmental Science-Policy Platform on Biodiversity and Ecosystem Services, Bonn, Germany. 892 pages.

IPBES. (2015).Report on the regional scoping process for a set of regional and subregional assessments (deliverable 2 (b)) Draft complementary scoping report for the regional assessment of biodiversity and ecosystem services for the Open Ocean region. https://www.ipbes.net/system/tdf/downloads/IPBES 36 Add.6 EN.pdf?file=1\&type=node\&id=1 $\underline{3059}$ Accessed 19 March 2019

JNCC, 2018. Natural capital work in JNCC. Position paper for The one-hundred-and-twelfth meeting of the Joint Nature Conservation Committee. http://jncc.defra.gov.uk/pdf/jncc_17_37_natural_capital_work_in_jncc\%20final.pdf

Jones, L., Angus, S., Cooper, A., Doody, P., Everard, M., Garbutt, A. et al. (2011). Chapter 11: Coastal Margins The UK National Ecosystem Assessment: Technical Report. (pp. 411-458). Cambridge: UNEP-WCMC.

Karjalainen, T. P., Marttunen, M., Sarkki, S., \& Rytkönen, A. M. (2013). Integrating ecosystem services into environmental impact assessment: an analytic-deliberative approach. Environmental Impact Assessment Review, 40, 54-64.

La Notte, A., D’Amato, D., Mäkinen, H., Paracchini, M. L., Liquete, C., Egoh, B. et al. (2017). Ecosystem services classification: A systems ecology perspective of the cascade framework. Ecological Indicators, 74, 392-402.

Laurans, Y., Rankovic, A., Billé, R., Pirard, R., \& Mermet, L. (2013). Use of ecosystem services economic valuation for decision making: Questioning a literature blindspot. Journal of environmental management, 119, 208-219.

Liquete, C., Piroddi, C., Drakou, E. G., Gurney, L., Katsanevakis, S., Charef, A., \& Egoh, B. (2013). Current status and future prospects for the assessment of marine and coastal ecosystem services: as systematic review. PLoS One, 8(7), e67737.

Lovett, A., Turner, K., Sünnenberg, G., Ferrini, S., Stephanou, E., \& Greaves, S. (2018). A natural capital asset check and risk register for the Anglian Water combined services area. Report to Anglian Water Services Ltd.

Lucieer V, Walsh P, Flukes E, Butler C,Proctor R, Johnson C (2017). Seamap Australia - a national seafloor habitat classification scheme. Institute for Marine and Antarctic Studies (IMAS), University of Tasmania (UTAS). https://seamapaustralia.org/. Accessed 19 March 2019

Luck, G. W., Daily, G. C., \& Ehrlich, P. R. (2003). Population diversity and ecosystem services. Trends in Ecology \& Evolution, 18(7), 331-336.

Mace, G. M., Hails, R. S., Cryle, P., Harlow, J., \& Clarke, S. J. (2015). Towards a risk register for natural capital. Journal of Applied Ecology, 52, 641-653.

Maes, J., Teller, A., Erhard, M., Grizzetti, B., Barredo, J. I., Paracchini, M. L. et al. (2018). Mapping and assessment of ecosystems and their services: An analytical framework for ecosystem condition. Luxembourg: Publications office of the European Union.

Maes, J., Teller, A., Erhard, M., Liquete, C., Braat, L., Berry, P. et al. (2013). Mapping and assessment of ecosystems and their services. An analytical framework for ecosystem assessments under action 5 of the EU biodiversity strategy to 2020. Luxembourg: Publications office of the European Union.

Maskell, L.C., Norton, L.R., Smart, S.M., Carey, P.D., Murphy, J., Chamberlain, P.M., Wood, C.M., Bunce, R.G.H. and Barr, C.J. (2008) Countryside Survey CS Technical Report No.1/07 Field Mapping Handbook. Centre for Ecology and Hydrology. November 2008. http://nora.nerc.ac.uk/id/eprint/5194/1/N005194CR.pdf Accessed 16 November 2018 
McBreen, F., Askew, N., Cameron, A., Connor, D., Ellwood, H. \& Carter, A. 2011. UKSeaMap 2010: Predictive mapping of seabed habitats in UK waters. JNCC Report, No. 446

Millennium Ecosystem Assessment. (2003). Ecosystems and human well-being. A Framework for Assessment. Washington D.C.: Island Press.

Natural Capital Coalition. (2018) Natural capital protocol for the Ocean.

https://naturalcapitalcoalition.org/projects/oceans-supplement/ Accessed 19 March 2019

Natural Capital Coalition. (2016). Natural capital protocol principles and framework. https://naturalcapitalcoalition.org/natural-capital-protocol/

Natural Capital Committee. (2017). How to do it: a natural capital workbook. Department for Environment Food and Rural Affairs. 30pp. https://www.gov.uk/government/groups/naturalcapital-committee

Natural Capital Committee. (2015). The state of natural capital. protecting and improving natural capital for prosperity and well-being. Third report to the Economic Affairs Committee. Department for Environment Food and Rural Affairs. 73pp.

https://www.gov.uk/government/publications/natural-capital-committees-third-state-of-naturalcapital-report

Natural Capital Committee. (2014). Towards a framework for defining and measuring changes in natural capital. Working Paper 1. Department for Environment Food and Rural Affairs. https://www.gov.uk/government/publications/natural-capital-committee-initial-term-workingpapers-2012-to-2015

Natural Capital Committee. (2013). The State of Natural Capital. Protecting and Improving Natural Capital for Prosperity and Wellbeing. Third report to the Economic Affairs Committee. https://assets.publishing.service.gov.uk/government/uploads/system/uploads/attachment_data/fil e/516725/ncc-state-natural-capital-third-report.pdf

NOAA. (Undated). Coastal and Marine Ecological Classification Standard (CMECS) https://iocm.noaa.gov/cmecs/index.html. Accessed 19 March 2019

North Devon and Torridge Local Plan, (2014). Publication Draft (Committee Version) April 2014. Torridge District Council, North Devon Council.

Norton, D., \& Hynes, S. (2014). Valuing the non-market benefits arising from the implementation of the EU Marine Strategy Framework Directive. Ecosystem Services, 10, 84-96. doi:10.1016/j.ecoser.2014.09.009

ONS (Office for National Statistics). (2018). UK natural capital: Ecosystem service accounts 1997 to 2015. Statistical bulletin. 12 February 2018. Office for National Statistics. https://www.ons.gov.uk/economy/nationalaccounts/uksectoraccounts/methodologies/naturalcapit al

ONS (Office for National Statistics). (2016). Scoping UK coastal margin ecosystem accounts. https://www.ons.gov.uk/economy/nationalaccounts/uksectoraccounts/methodologies/naturalcapit al

Partidário, M. R. (2010) TEEB case: SEA for including ecosystem services in coastal management, Portugal, available at: www.TEEBweb.org

Petersen, J.E. (2017). Developing an EU Ecosystem Accounting System Focus on marine ecosystems. Paris, 10 - 11 March 2016. Draft Workshop Report

Potts, T., Burdon, D., Jackson, E., Atkins, J., Saunders, J., Hastings, E., \& Langmead, O. (2014). Do marine protected areas deliver flows of ecosystem services to support human welfare? Marine Policy, 44, 139-148. doi: 10.1016/j.marpol.2013.08.011

Primmer, E., Saarikoski, H., \& Vatn, A. (2018). An Empirical Analysis of Institutional Demand for Valuation Knowledge. Ecological Economics, 152, 152-160.

Rees, S.E., Ashley, M., Cameron, A. (2018). Executive Summary: North Devon Marine Pioneer, links between the ecosystem and ecosystem services in the North Devon Marine Pioneer. A report to WWF-UK by research staff the Marine Institute at University of Plymouth. 
Rosenberg, A., Bigford, T. E., Leathery, S., Hill, R. L., \& Bickers, K. (2000). Ecosystem approaches to fishery management through essential fish habitat. Bulletin of marine science, 66(3), 535-542.

Rozas-Vásquez, D., Fürst, C., Geneletti, D., \& Muñoz, F. (2017). Multi-actor involvement for integrating ecosystem services in strategic environmental assessment of spatial plans. Environmental Impact Assessment Review, 62, 135-146.

RSPB (Royal Society for the Protection of Birds). (2017). Accounting for nature: a natural capital account of the RSPB's estate in England. RSPB. 42.pp. https://www.rspb.org.uk/globalassets/downloads /documents/positions/economics/accounting-for-nature.pdf

Ruijs A. et al. (2018), Natural Capital Accounting for the Sustainable Development Goals. Current and potential uses and steps forward. PBL Netherlands Environmental Assessment Agency, The Hague.

Russel, D., Turnpenny, J., Jordan, A., Bond, A., Sheate, W., \& Adelle, C. (2014). UK National Ecosystem Assessment Follow-on. Work Package Report 9: Embedding an ecosystem services framework in appraisal: key barriers and enablers. UK: UNEP-WCMC, LWEC.

Saunders, J., Tinch, R., \& Hull, S. (2010). Valuing the marine estate and UK seas: an ecosystem services framework: London, The Crown Estate.

Sayre, R. G., Wright, D. J., Breyer, S. P., Butler, K. A., Van Graafeiland, K., Costello, M. J., Harris, P. T., Goodin, K. L., Guinotte, J. M., Basher, Z., Kavanaugh, M. T., Halpin, P. N., Monaco, M. E., Cressie, N., Aniello, P., Frye, C. E. \& Stephens, D. (2017). A threedimensional mapping of the ocean based on environmental data. Oceanography, 30 (1), 90-103.

Scott, A., Carter, C., Hölzinger, O., Everard, M., Rafaelli, D., Hardman, M., Baker, J., Glass, J., Leach, K., Wakeford, R., Reed, M., Grace, M., Sunderland, T., Waters, R., Corstanje, R., Glass, R., Grayson, N., Harris, J., \& Taft, A. (2014) UK National Ecosystem Assessment Follow-on. Work Package Report 10: Tools - Applications, Benefits and Linkages for Ecosystem Science (TABLES). UNEP-WCMC, LWEC, UK.

Scottish Government. (2018, 05/05/2018). National Indicators Retrieved 16/05/18, 2018, from http://www.gov.scot/About/Performance/scotPerforms/indicator

Scottish Government (2016). Integrating an Ecosystems Approach into Strategic Environmental Assessment. Information Note. https://www2.gov.scot/Topics/Environment/environmentalassessment/sea/SEAGuidance/Ecosystems-Approach Accessed 13 November 2018

Scottish Natural Heritage. (2018a). Scotland's Natural Capital Asset Index. Technical Guidance. https://www.nature.scot/scotlands-natural-capital-asset-index-0

Scottish Natural Heritage. (2018b). Scotland's Natural Captial Asset Index. Information Note Updated 2018. https://www.nature.scot/scotlands-natural-capital-asset-index-0

South African National Biodiversity Institute. (2011) National Biodiversity Assessment 2011 Marine and Benthic Coastal Habitat Types. http://bgis.sanbi.org/SpatialDataset/Detail/414

Spackman, M. (2013). Handling non-monetised factors in project, programme and policy appraisal: Centre for Climate Change Economics and Policy, Grantham Research Institute on Climate Change and the Environment.

Statistics Netherlands and Wageningen University. 2017. The SEEA EEA carbon account for the Netherlands. June 2017. The Hague.

Steinbach, N. (2017). How Environmental Accounts in Sweden Are Driven by Changing Policy Need In M. Vardon, S. Bass, S. Ahlroth \& A. Ruijs (Eds.). Forum on natural capital accounting for better policy decisions: taking stock and moving forward. Washington D.C.: World Bank. Wealth Accounting and the Valuation of Ecosystem Services.

TEEB. (2010). The Economics of Ecosystems and Biodiversity: Ecological and Economic Foundations. London: Earthscan.http://www.teebweb.org/our-publications/teeb-studyreports/ecological-and-economic-foundations/

TEEB. (2013). TEEB for Oceans and Coasts. http://doc.teebweb.org/wpcontent/uploads/2013/04/2013-Oceans-and-Coasts-Flyer.pdf accessed 19 March 2019 
Tillin, H.M., Langmead, O., Hodgson, B., Luff, A, Rees, S., Hooper, T. Frost, M. 2019. Feasibility study for a Marine Natural Capital Asset Index for Scotland. Scottish Natural Heritage Research Report No. 1071

Tinch, R., Cryle, P., Mathieu, L., Rudd, T., Fredenham, E., Corbelli, D., \& Newhill, L. (2014). Baseline evaluation of environmental appraisal and sustainable development guidance across Government. Report for Department for the Environment, Food and Rural Affairs.

Torres, C., \& Hanley, N. (2017). Communicating research on the economic valuation of coastal and marine ecosystem services. Marine Policy, 75, 99-107.

Turner, R. K., Schaafsma, M., Elliott, M., Burdon, D., Atkins, J., Jickells, T. et al. (2014). UK National Ecosystem Assessment Follow-on. Work Package Report 4: Coastal and marine ecosystem services: principles and practice. UK: UNEP-WCMC, LWEC.

Turner RK, Schaafsma M, Mee L, Elliott M, Burdon D, Atkins JP, Jickells T. (2015). Conceptual framework. In: Turner RK, Schaafsma M, editors. Coastal zones ecosystem services: From science to values and decision making. Studies in ecological economics. Vol 9. Berlin (DE): Springer. p 11-40.

UK National Ecosystem Assessment. (2011). The UK National Ecosystem Assessment Follow On: Synthesis of Key Findings. Cambridge: UNEP-WCMC. http://uknea.unepwcmc.org/Resources/tabid/82/Default.aspx

UK National Ecosystem Assessment. (2014). The UK National Ecosystem Assessment: Technical Report. Cambridge: UNEP-WCMC. http://uknea.unep-wcmc.org/Resources/tabid/82/Default.aspx

United Nations. (2018). A Regular Process for Global Reporting and Assessment of the State of the Marine Environment, including Socio-economic Aspects. Outline of the Second World Ocean Assessment. https://www.un.org/regularprocess/sites/www.un.org.regularprocess/files/outline for the second world ocean assessment rev.pdf. Accessed 19 March 2019

United Nations Division for Ocean Affairs and the Law of the Sea. (2016). A Regular Process for Global Reporting and Assessment of the State of the Marine Environment, including Socioeconomic Aspects (Regular Process).

http://www.un.org/depts/los/global_reporting/WOA_RegProcess.htm. Accessed 19 March 2019

United Nations, \& Food and Agriculture Organization of the United Nations. (2004). Handbook of national accounting integrated environmental and economic accounting for fisheries. Studies in Methods, Series F, No.97 (ST/ESA/STAT/SER.F/97).

United Nations, European Union, Food and Agriculture Organization of the United Nations, Organisation for Economic Co-operation and Development, \& World Bank. (2014a). System of Environmental-Economic Accounting 2012-experimental ecosystem accounting. New York: United Nations. https://unstats.un.org/unsd/envaccounting/seearev/eea_final_en.pdf

United Nations, European Union, Food and Agriculture Organization of the United Nations, International Monetary Fund, Organisation for Economic Co-operation and Development, \& World Bank. (2014b). System of Environmental-Economic Accounting 2012-central framework. New York: United Nations.

https://unstats.un.org/unsd/envaccounting/seearev/seea_cf_final_en.pdf

United Nations. (1993). Integrated environmental and economic accounting. Interim Version. Handbook of National Accounting. Studies in Methods Series F, No.31. Department for Economic and Social Information and Policy Analysis, Statistical Division. New York: United Nations.

United States Environmental Protection Agency. (2015). National Ecosystem Services Classification System (NESCS): Framework Design and Policy Application. EPA-800-R-15-002. . Washington DC: United States Environmental Protection Agency.

Vardon, M., Bass, S., Ahlroth, S., \& Ruiijs, A. (2017). In M. Vardon, S. Bass, S. Ahlroth \& A. Ruijs (Eds.). Forum on natural capital accounting for better policy decisions: taking stock and moving forward. Washington D.C.: World Bank. Wealth Accounting and the Valuation of Ecosystem Services. 
Vivid Economics. (2017). Natural capital accounts for public green space in London. Report prepared for Greater London Authority, National Trust and Heritage Lottery Fund.

Wallace, K. (2007). Classification of ecosystem services: Problems and solutions. Biological Conservation, 139, 235-246.

Weatherdon, L. V. (2018). Horizon scan of priorities for European marine pilot accounts. Report prepared for the European Commission.

Weatherdon, L. V., Friedrich, L. A., Martin, C. S., \& King, S. (2017). Experimental Seagrass Ecosystem Accounts: A pilot study for one component of marine ecosystem accounts. Report prepared for the European Commission.

White, C., Dunscombe, R., Dvarskas, A., Eves, C., Finisdore, J., Kieboom, E. et al. (2015a). Developing ecosystem accounts for protected areas in England and Scotland: Main Report. Department for Food, Environment \& Rural Affairs/The Scottish Government.

White, C., Dunscombe, R., Dvarskas, A., Eves, C., Finisdore, J., Kieboom, E. et al. (2015b). Developing ecosystem accounts for protected areas in England and Scotland: Technical appendix. Department for Food, Environment \& Rural Affairs/The Scottish Government.

Wood, S. L., Jones, S. K., Johnson, J. A., Brauman, K. A., Chaplin-Kramer, R., Fremier, A., ... \& Mulligan, M. (2018). Distilling the role of ecosystem services in the Sustainable Development Goals. Ecosystem services, 29, 70-82.

World Resources Institute (2013) Weaving Ecosystem Services into Impact Assessment. A step-bystep methods. Version 1.0. Washington 